\section{ЯКІСТЬ ЖИТТЯ В КPAÏHAX ЄС: ОСНОВНІ ТЕНДЕНЦІї}

дєЛІНІ М. М., доктор економічних наук, доцент, професор кафедри виробничого та інвестиційного менеджменту Національного університету біоресурсів і природокористування України

\section{QUALITY OF LIFE IN EU COUNTRIES: MAIN TRENDS}

\author{
DIELINI M., \\ Doctor of Science in Economics, \\ Associate Professor, Professor of \\ the Department of Production and \\ Investment Management, \\ National University of Life and \\ Environmental Sciences of Ukraine
}

В статті проаналізовано якість життя населення Європейського Союзу за різними індексами та показниками. Визначено сутність якості життя, багатогранність цієї категорії та різносторонність ії складових. Проведено дослідження країн Європейського Союзу та інших країн Європи й порівняно з Україною. Досліджено основні тенденції та можливі фактори впливу на сучасний стан розвитку якості життя країн Європи.

Ключові слова: якість життя, Індекс Людського Розвитку, Індекс якості життя, Європейський Союз, індекс доходів, диференціація доходів.

В статье проанализировано качество жизни населения Европейского Союза по разным индексам и показателям. Определены сущность качества жизни, многогранность этой категории и разносторонность ее составляющих. Проведены исследования стран Европейского Союза и других стран Европы по сравнению с Украиной. Исследованы основные тенденции и возможные факторы влияния на современное состояние развития качества жизни Европы.

Ключевые слова: качество жизни, Индекс Человеческого Развития, Индекс качества жизни, Европейский Союз, индекс доходов, дифференциация доходов.

The article analyzes the quality of life of the population of the European Union according to various indices and indicators. The essence of the quality of life, versatility of this category and multifaceted of its components are determined. The research of the European Union and other European countries and in comparison with Ukraine is conducted. The main trends and possible factors influencing the current state of development of quality of life in Europe are studied.

Key words: quality of life, Human Development Index, Quality of Life Index, European Union, income index, income differentiation.

Постановка проблеми. Дослідження якості життя Європейського Союзу $(€ C) \in$ актуальним питанням через євроінтеграційний курс України та необхідності відповідності певним критеріям та цінностям $€ C$. $€$ в сучасному світі $€$ вагомим угрупованням країн, до якого входять 27 країн Європи 3 населенням 447 млн осіб станом на 01.01.2021 р. Таким чином, ЄС покриває більшу частину континенту Європа та займає позицію лідера як економічного, так і політичного.

Аналіз останніх досліджень та публікацій. Проблемою своїх наукових інтересів дослідження якості життя як $Є C$ в цілому, так й у світі взагалі зробили не тільки науковці й дослідники (Е. М. Лібанова, О. М. Гладун, Л. С. Лісогор, М. М. Дєліні, М. О. Нестерова та ін.), але й світові організації та міжнародні проєкти, які як результат своїх досліджень формують різноманітні індекси, за якими може бути 
оцінена якість життя населення. Серед них можна виділити Програму ООН з розвитку та її Індекс Людського Розвитку та проєкт Numbeo та Індекс якості життя. В даному дослідженні статистичні дані вищезазначених індексів буде використано для аналізу розвитку ЄС за якістю життя та порівняння з Україною.

Метою статті є дослідження якості життя населення ЄС та інших країн Європи за різними індикаторами та їхнє порівняння.

Виклад основного матеріалу дослідження. Для аналізу якості життя $€ C$ наведемо теоретичне значення цієї категорії. Термін "якість життя» використовується для позначення загального добробуту людей та суспільства. В глобальному значенні якість життя можна охарактеризувати як ступінь задоволення матеріальних, культурних і духовних потреб людини [1]. 3 огляду на це трактування ми бачимо, що поняття якості життя достатньо багатогранне та $є$ якісним за своєю суттю, тобто його кількісний вимір ускладняється через не тільки економічний характер, але й соціальний.

Термін якість життя за своєю суттю неоднозначний, оскільки він може стосуватися як досвіду, який людина має у своєму власному житті, так і умов життя, в яких перебувають люди. Отже, якість життя ще $€$ й суб'єктивним через можливість різнопланового трактування індивідами. Тоді як одна людина може визначати якість життя відповідно до багатства чи задоволеності життям, інша людина може визначати це з точки зору можливостей (наприклад, мати здатність жити добре життя з точки зору емоційного та фізичного благополуччя). Люди з особливими потребами можуть повідомляти про високу якість життя, тоді як здорова людина, яка нещодавно втратила роботу, може повідомити про низьку якість життя.

Як уже зазначалось, якість життя є якісною характеристикою за своєю сутністю, до яких ми відносимо ті показники, які характеризують якість життя в країні, що не може бути виражена в числовому вигляді. Це задоволеність населення рівнем та якістю життя в країні, рівень та якість життя, які вимірюються Індексом людського розвитку, що складається із багатьох складових, які враховують як соціальну, так і економічну сферу. Аналізуючи його зміст, можна сказати, що Індекс людського розвитку (ІЛР) $€$ одним 3 основних показників, який відображає якість життя громадян. Індекс людського розвитку інтегральний рейтинговий показник, що характеризує ступінь задоволення потреб людини та рівень забезпечення ії прав. Сам ІЛР включає в себе показники ВВП на душу населення, який розрахований в дол. США в перерахунку на ціни всередині країни, загальний рівень грамотності населення та очікувана кількість років, яка витрачається на освіту, очікувана тривалість життя.

Взагалі, вважається, що ІЛР $€$ сумарним виміром досягнень в трьох напрямках людського розвитку: тривалість життя, доступ до знань та доцільний рівень життя. У методиці ПРООН розрахунку цього індексу розглядається три індикатори добробуту: очікувана тривалість життя при народженні, освітні досягнення та реальний ВВП на особу [2]. Тобто, показники, які входять до складу ІЛР, і формують добробут населення.

Для нашого дослідження й виміру якості життя населення ЄС проаналізуємо його результати. У таблиці 1 представимо результат Індексу людського розвитку у 2019 р., який наведено у Звіті Людського Розвитку 2020 р. В даній таблиці представлений рейтинг країн, який враховую світову позицію, а не за регіоном Європи, також 
представлено загальний показник Індексу, рівень очікуваної тривалості життя, очікувана тривалість та середня тривалість навчання у школі та рівень доходу, а душу населення. Отже, ці показники включають не тільки економічні показники, але й соціальні, що цілком логічно розкриває сутність самого поняття якості життя.

Індекс Людського Розвитку країн Європи у 2019 р. *

\begin{tabular}{|c|c|c|c|c|c|c|}
\hline $\begin{array}{l}\text { Рей- } \\
\text { тинг }\end{array}$ & Країна & $\begin{array}{l}\text { Показник } \\
\text { Індексу }\end{array}$ & $\begin{array}{c}\text { Рівень } \\
\text { очікуваної } \\
\text { тривалості } \\
\text { життя, } \\
\text { роки }\end{array}$ & $\begin{array}{c}\text { Очікувана } \\
\text { кількість } \\
\text { років } \\
\text { навчання } \\
\text { в школі, } \\
\text { роки }\end{array}$ & $\begin{array}{c}\text { Середня } \\
\text { кількість } \\
\text { років } \\
\text { навчання } \\
\text { в школі, } \\
\text { роки }\end{array}$ & $\begin{array}{c}\text { Валовий } \\
\text { національний } \\
\text { дохід на } \\
\text { душу } \\
\text { населення, } \\
\text { дол. США }\end{array}$ \\
\hline 1 & Норвегія & 0,957 & 82,4 & 18,1 & 12,9 & 66494 \\
\hline 2 & Ірландія & 0,955 & 82,3 & 18,7 & 12,7 & 68371 \\
\hline 2 & Швейцарія & 0,955 & 83,8 & 16,3 & 13,4 & 69394 \\
\hline 4 & Ісландія & 0,949 & 84,9 & 19,1 & 12,8 & 54682 \\
\hline 6 & Німеччина & 0,947 & 81,3 & 17,0 & 14,2 & 55314 \\
\hline 7 & Швеція & 0,945 & 82,8 & 19,5 & 12,5 & 54508 \\
\hline 8 & Нідерланди & 0,944 & 82,3 & 18,5 & 12,4 & 57707 \\
\hline 10 & Данія & 0.940 & 80,9 & 18,9 & 12,6 & 58662 \\
\hline 11 & Фінляндія & 0,938 & 81,9 & 19,4 & 12,8 & 48511 \\
\hline 13 & $\begin{array}{l}\text { Велика } \\
\text { Британія }\end{array}$ & 0,932 & 81,3 & 17,5 & 13,2 & 46071 \\
\hline 14 & Бельгія & 0,931 & 81,6 & 19,8 & 12,1 & 52085 \\
\hline 18 & Австрія & 0,922 & 81,5 & 16,1 & 12,5 & 56197 \\
\hline 19 & Ліхтенштейн & 0,919 & 80,7 & 14,9 & 12,5 & 131032 \\
\hline 22 & Словенія & 0,917 & 81,3 & 17,6 & 12,7 & 38080 \\
\hline 23 & Люксембург & 0,916 & 82,3 & 14,3 & 12,3 & 72712 \\
\hline 24 & Іспанія & 0,904 & 83,6 & 17,6 & 10,3 & 40975 \\
\hline 26 & Франція & 0,901 & 82,7 & 15,6 & 11,5 & 47173 \\
\hline 27 & Чехія & 0,900 & 79,4 & 16,8 & 12,7 & 38109 \\
\hline 28 & Мальта & 0,895 & 82,5 & 16,1 & 11,3 & 39555 \\
\hline 29 & Естонія & 0,892 & 78,8 & 16,0 & 13,1 & 36019 \\
\hline 29 & Італія & 0,892 & 83,5 & 16,1 & 10,4 & 42776 \\
\hline 32 & Греція & 0,888 & 82,2 & 17,9 & 10,6 & 30155 \\
\hline 33 & Кіпр & 0,887 & 81,0 & 15,2 & 12,2 & 38207 \\
\hline 34 & Литва & 0,882 & 75,9 & 16,6 & 13,1 & 35799 \\
\hline 35 & Польща & 0,880 & 78,7 & 16,3 & 12,5 & 31623 \\
\hline 36 & Андорра & 0,868 & 81,9 & 13,3 & 10,5 & 56000 \\
\hline 37 & Латвія & 0,866 & 75,3 & 16,2 & 13,0 & 30282 \\
\hline 38 & Португалія & 0,864 & 82,1 & 16,5 & 9,3 & 33967 \\
\hline 39 & Словаччина & 0,860 & 77,5 & 14,5 & 12,7 & 32113 \\
\hline 40 & Угорщина & 0,854 & 76,9 & 15,2 & 12,0 & 31329 \\
\hline 43 & Хорватія & 0,851 & 78,5 & 15,2 & 11,4 & 28070 \\
\hline 49 & Румунія & 0,828 & 73,9 & 15,8 & 12,5 & 19317 \\
\hline 56 & Болгарія & 0,816 & 75,1 & 14,4 & 11,4 & 23325 \\
\hline 74 & Україна & 0,779 & 72,1 & 15,1 & 11,4 & 13216 \\
\hline
\end{tabular}

*Таблицю побудовано автором на основі [3].

Аналіз таблиці 1 дає можливість побачити, що серед лідерів світових за цим показником є країна, яка не відноситься до країн ЄС, але ії постійним партнером та входить до Шенгенської Угоди Норвегія. За результатами таблиці наочно видно, що якість життя $є$ інтегральним показником, так як висока позиція Норвегії спирається більше на соціальні показники ніж економічні. Так, рівень доходу на душу населення є меншим Ірландії та Швейцарії, але тривалість життя громадян Норвегії перевищує Ірландію й трохи поступається Швейцарії. Так само варто відмітити, що Ірландія та Швейцарія 
поділяють 2 позицію в рейтингу відрізняючись високим показником доходу на душу населення, який перевищують лише показники Ліхтенштейну та Люксембургу, що пояснюється розмірами цих країн та кількістю населення. Також за прикладом Ліхтенштейну та Люксембургу, які посідають 19 та 23 місце у рейтингу відповідно, можемо зробити висновок, що економічні показники не є основними для людського розвитку й для формування якості життя, хоча, безумовно, дуже важливими.

Ісландія, яка також не є країною-членом ЄС займає 4 місце, що обґрунтовується довгою тривалістю життя громадян цієї країни.

Якщо узагальнити дані таблиці, то побачимо, що країни-члени ЄC вкладаються в перші 50 позицій (за винятком Болгарії, яка посідає 56 місце у рейтингу).

Найменші показники тривалості життя, що очікується в Румунії $(73,9)$, Латвії $(75,3)$, Литві $(75,9)$, що $€$ невеликою тривалістю в порівнянні з $Є С$, але більшого показника України в 72,1.

Якщо аналізувати за рівнем доходу на душу населення, то показник України є також найменшим (13216 дол. США), хоча й кількість населення нашої країни $€$ доволі високою в порівнянні 3 іншими країнами Європи.

Серед сучасних членів ЄС найменший показник рівня доходу на душу населення в Румунії - 19317 дол. США, що відчутно нижче інших країн. Серед нових членів ЄС (які увійшли у 2004, 2007 та 2013 роках), найкраща позиція за цим Індексом у Словенії - 22 місце у рейтингу, за якою йдуть країни, які ще раніше були членами ЄС та вважаються найбільш розвиненими країнами Європи та світу.

В монографії автора було запропоновано фази розвитку ІЛР України до 2016 р. включно. Так, нами було виділено 5 фаз:

І фаза - зниження - 1991-1996 рр. - пов'язана із отриманням Україною незалежності та погіршенням економічної ситуації в країні. Для вирішення проблем Україні знадобилось 5 років, щоб провести грошову реформу та покращити ситуацію в країні.

II фаза - стабільне зростання - 1996-2008 рр. - характеризується покращенням економічної та соціальної ситуації в країні, проведенням державою заходів щодо підвищення добробуту країни. Але закінчується ця стадія світовою економічною кризою та зниженням ІЛР y 2009 p.

III фаза - нетривалий спад - 2009 р. - світова економічна криза, що привела до зниження світової економіки в цілому та мала наслідки й для України, але вчасно були прийняти заходи, що дозволило в розвитку ІЛР говорити про наступну фазу.

IV фаза - поступове зростання - 2009-2014 рр. - почалась з 2009 р. після закінчення світової економічної кризи та відрізнялась поступовим нарощуванням економічного потенціалу країни, а також підвищенням ІЛР.

V фаза - стрімке зниження - 2014-2016 рр. - ІЛР України характеризується стрімким зниженням, що пов'язано із загостренням політичної, економічної, соціальної та військової ситуації в країні. 3 урахуванням того, що ІЛР залежить як від економічних, так і соціальних показників, то й ця ситуація одразу відбивається на стані показника ІЛР [Моно].

Ми можемо додати нову VI стадію - вирівнювання та зростання у 2019 р. зафіксовано повільний прогрес й значення іiї показника дорівнює 0,779, що дає можливість віднести Україну до країн високого 
рівня людського розвитку (74 місце серед 189 країн). Цю позицію Україна займає разом з такими країнами як Гренада, Мексика, СентКітс і Невіс. В цілому, відмічається зростання показника ІЛР нашої країни на 7,4 відсотка за період у 29 років (1990-2019рр.) [4], що є позитивною характеристикою та дає підґрунтя для соціального та економічного розвитку нашої країни та повноцінної її готовності до вступу до ЄС, поділу його цінностей та відповідності критеріям.

Також можна виділити ще інший показник, який вимірює якість життя - Індекс якості життя від міжнародного проєкту Numbeo, який щороку складає рейтинг країн за цим індексом. Цей індекс включає в себе такі критерії: індекс купівельної спроможності (IKC), індекс безпеки (ІБ), індекс охорони здоров'я (IO3), індекс вартості життя (IBЖ), індекс забруднення (I3), кліматичний індекс (IK) та ін. Результати ЄС та інших країн Європи за 2020 р. можна навести у таблиці 2.

Таблиця 2

Індекс якості життя ЄС та інших країн Європи, 2020 р. *

\begin{tabular}{|c|c|c|c|c|c|c|c|c|}
\hline $\begin{array}{l}\text { Рей- } \\
\text { тинг }\end{array}$ & Країна & $\begin{array}{l}\text { Індекс } \\
\text { якості } \\
\text { життя }\end{array}$ & IKC & IE & 103 & IBЖ & 13 & IK \\
\hline 1 & Швейцарія & 188,36 & 102,77 & 78,38 & 74,08 & 125,02 & 19,86 & 80,05 \\
\hline 2 & Данія & 186,25 & 86,43 & 73,78 & 79,79 & 88,53 & 25,39 & 87,00 \\
\hline 3 & Нідерланди & 180,27 & 76,65 & 72,84 & 75,28 & 78,93 & 25,39 & 87,00 \\
\hline 4 & Фінляндія & 178,95 & 80,11 & 72,41 & 76,19 & 76,35 & 11,99 & 56,64 \\
\hline 5 & Тсландія & 177,64 & 67,30 & 76,25 & 65,85 & 99,67 & 15,97 & 68,81 \\
\hline 6 & Австрія & 176,36 & 68,69 & 74,46 & 76,98 & 74,87 & 20,42 & 77,15 \\
\hline 7 & Німеччина & 175,24 & 89,86 & 64,21 & 73,49 & 67,85 & 27,81 & 82,82 \\
\hline 8 & Люксембург & 171,81 & 87,76 & 65,87 & 72,92 & 85,30 & 23,27 & 82,62 \\
\hline 9 & Норвегія & 171,72 & 73.55 & 66,28 & 75,59 & 103,56 & 18,09 & 68,68 \\
\hline 10 & Естонія & 171,16 & 56,58 & 76,29 & 72,68 & 53,77 & 19,72 & 64,28 \\
\hline 11 & Швеція & 179,19 & 85,44 & 52,00 & 68,82 & 75,89 & 18,46 & 74,92 \\
\hline 12 & Словенія & 165,74 & 52,08 & 77,72 & 65,19 & 56,40 & 22,65 & 77,56 \\
\hline 13 & Іспанія & 163,48 & 58,50 & 66,68 & 78,85 & 56,64 & 39,73 & 93,65 \\
\hline 14 & Литва & 160,29 & 52,80 & 66,58 & 70,91 & 46.04 & 26,67 & 69,86 \\
\hline 15 & Португалія & 159,83 & 40,54 & 70,09 & 71,85 & 50,65 & 30,19 & 97,81 \\
\hline 16 & Чехія & 157,49 & 54,80 & 74,48 & 75,39 & 48,20 & 36,31 & 77,13 \\
\hline 17 & $\begin{array}{l}\text { Велика } \\
\text { Британія }\end{array}$ & 156,94 & 77,47 & 53,93 & 75,11 & 70,64 & 40,10 & 88,21 \\
\hline 18 & Хорватія & 155,42 & 39,83 & 75,41 & 63,95 & 55,18 & 30,84 & 89,69 \\
\hline 19 & Франція & 153,60 & 76,36 & 48,01 & 80,56 & 77,59 & 42,17 & 90,41 \\
\hline 20 & Ірландія & 150,54 & 71,58 & 54,49 & 52,82 & 78,55 & 33,86 & 89,13 \\
\hline 21 & Бельгія & 148,18 & 70,12 & 55,42 & 75,37 & 75,79 & 50,09 & 86,03 \\
\hline 22 & Словаччина & 147,09 & 45,65 & 69,63 & 60,19 & 47,32 & 39,50 & 78,13 \\
\hline 23 & Латвія & 146,80 & 43,49 & 61,23 & 62,02 & 50,41 & 33,23 & 74,70 \\
\hline 24 & Італія & 137,77 & 54,30 & 55,15 & 66,99 & 69,99 & 54,06 & 91,48 \\
\hline 25 & Угорщина & 134,54 & 47,41 & 65,64 & 52,85 & 42,26 & 48,12 & 79,48 \\
\hline 26 & Румунія & 130,86 & 41,89 & 71,70 & 55,98 & 36,77 & 58,65 & 77,62 \\
\hline 27 & Греція & 127,96 & 35,95 & 54,15 & 57,09 & 58,38 & 52,10 & 92,49 \\
\hline 28 & Польща & 127,79 & 43,61 & 69,50 & 56,15 & 41,75 & 57,34 & 76,01 \\
\hline 29 & Болгарія & 126,88 & 39,49 & 61,79 & 56,28 & 38,67 & 64,54 & 82,76 \\
\hline 33 & Україна & 107,80 & 30,28 & 52,58 & 53,70 & 31,20 & 63,59 & 70,69 \\
\hline
\end{tabular}

*Таблицю побудовано автором на основі [5].

Цей Індекс оцінює якість життя також за соціально-економічними показниками та складається з різних важливих індексів. Як ми бачимо 3 таблиці 2, за цим Індексом країни Європи розподіляються трохи інакше. Варто зазначити, що рейтинг, який наведений в таблиці 2, $\epsilon$ рейтингом за регіоном Європа, а не в загальному по світу. За даним Індексом позиція лідера в Швейцарії, яка також не є членом $€ С$, але 
Норвегія, яка є лідером за попереднім Індексом, займає 9 сходинку в даному рейтингу.

В цілому Швейцарія та Данія (член $Є C$ ) посідають перші дві сходинки в Європі доволі вагомо випереджаючи інші країни, а різниця Швейцарії та України в загальному результаті Індексу дорівнює 80,56. В цілому, в 10-ку лідерів входять країни ЄС-15 (група країн, яка об'єдналась до 1995 р. включно), 3 країни, які не є членами ЄС, а також Естонія, що є вартим уваги показником, адже ця країна має схожу 3 Україною історію економічного розвитку.

Аналіз таблиці 2 відображає, що країни різняться за різними складовими: Швейцарія випереджає інші країни за Індексом купівельної спроможності та Індексом безпеки, Індексі Вартості життя, поступаючись позиціями в Індексі охорони здоров'я.

3 даним показником, як й в попередньому, країни, які приєднались до ЄС пізніше можуть випереджати країни, які були членами до 1995 р. Так, наприклад, Франція займає 19 сходинку, Бельгія - 21, а Італія - 24.

Далі проаналізуємо показник нерівності доходів серед населення, який відображає нерівномірність розподілу доходів, що також може характеризувати якість життя населення, адже це $€$ індикатором рівня розвитку суспільства та стратифікації суспільства.

Таблиця 3

Нерівність доходів (коефіцієнт Джіні)

\begin{tabular}{|l|c|c|c|c|c|}
\hline & 2010 & 2015 & 2018 & $\begin{array}{c}\text { Динаміка } \\
2015 \text { до }\end{array}$ & $\begin{array}{c}\text { Динаміка } \\
2018 \text { до } \\
2015\end{array}$ \\
\hline Австрія & 28,3 & 27,2 & 26,8 & $-1,1$ & $-0,4$ \\
\hline Бельгія & 26,6 & 26,2 & 25,6 & $-0,4$ & $-0,6$ \\
\hline Болгарія & 33,2 & 37 & 39,6 & 3,8 & 2,6 \\
\hline Велика Британія & 32,9 & 32,4 & $\mathrm{H} /$ д & $-0,5$ & - \\
\hline Греція & 32,9 & 34,2 & 32,3 & 1,3 & $-1,9$ \\
\hline Данія & 26,9 & 27,4 & 27,8 & 0,5 & 0,4 \\
\hline Естонія & 31,3 & 34,8 & 30,6 & 3,5 & $-4,2$ \\
\hline Ірландія & 30,7 & 29,7 & $\mathrm{H} / д$ & -1 & - \\
\hline Іспанія & 33,5 & 34,6 & 33,2 & 1,1 & $-1,4$ \\
\hline Італія & 31,7 & 32,4 & 33,4 & 0,7 & 1 \\
\hline Кіпр & 30,1 & 33,6 & 29,1 & 3,5 & $-4,5$ \\
\hline Латвія & 35,9 & 35,4 & 35,6 & $-0,5$ & 0,2 \\
\hline Литва & 37 & 37,9 & 36,9 & 0,9 & -1 \\
\hline Люксембург & 27,9 & 28,5 & $\mathrm{H} / д$ & 0,6 & - \\
\hline Мальта & 28,6 & 28,1 & 28,7 & $-0,5$ & 0,6 \\
\hline Нідерланди & 25,5 & 26,7 & 27 & 1,2 & 0,3 \\
\hline Німеччина & 29,3 & 30,1 & 31,1 & 0,8 & 1 \\
\hline Польща & 31,1 & 30,6 & 27,8 & $-0,5$ & $-2,8$ \\
\hline Португалія & 33,7 & 34 & 32,1 & 0,3 & $-1,9$ \\
\hline Румунія & 33,5 & 37,4 & 35,1 & 3,9 & $-2,3$ \\
\hline Словаччина & 25,9 & 23,7 & н/д & $-2,2$ & - \\
\hline Словенія & 23,8 & 24,5 & 23,4 & 0,7 & $-1,1$ \\
\hline
\end{tabular}




\begin{tabular}{|l|c|c|c|c|c|}
\hline Угорщина & 24,1 & 28,2 & 28,7 & 4,1 & 0,5 \\
\hline Фінляндія & 25,4 & 25,2 & 25,9 & $-0,2$ & 0,7 \\
\hline Франція & 29,8 & 29,2 & н/д & $-0,6$ & - \\
\hline Хорватія & 31,6 & 30,4 & 29,7 & $-1,2$ & $-0,7$ \\
\hline Чехія & 24,9 & 25 & 24 & 0,1 & -1 \\
\hline Швеція & 25,5 & 26,7 & 27 & 1,2 & 0,3 \\
\hline
\end{tabular}

Таким чином, аналіз таблиці дає можливість зробити висновок, що рівень нерівномірності доходів протягом періоду, що аналізується має різну динаміку за країнами, що наведено. Найменший показник у 2018 р. у Словенії $(23,4)$, Чехії $(24)$, Бельгії $(25,6)$ та Фінляндії $(25,9)$. Бельгія, Чехія та Словенія показують негативну динаміку цього показника, що можна охарактеризувати як зниження нерівномірності доходів.

Найбільший показник нерівності доходів у Болгарії (39,6 у 2018 р.), Литві $(36,9)$ та Латвії $(35,6)$. Ці країни відносяться до нових членів $€ C$, які приєднались у 2004 р. та 2007 р., що може обґрунтовувати такий результат, хоча й Словенія з Чехією, які мають найменші показники, так само були серед країн, що приєднались у 2004 р.

Аналіз динаміки цього показника відображує, що в порівнянні 3 2015 р. деякі країни знизили свою нерівність, а ті країни, що мають позитивний результат, не збільшили нерівність більше 1, що можна охарактеризувати як позитивні зміни.

Висновки та перспективи подальших досліджень. Отже, аналіз статистичних даних дає можливість зробити висновок, що країни ЄС та інші країни Європи можна охарактеризувати як країни 3 однією 3 найвищою якістю життя, оскільки Європейські країни є лідерами Індексу Людського Розвитку, а також серед Індексу якості життя мають доволі високі показники. Варто відмітити, що серед лідерів $€$ як країничлени ЄС (Данія, Німеччина, Фінляндія), так й країн, які не є членами $€ C$ - Норвегія, Швейцарія, Ісландія. Даний результат не означає, що ті, хто не є членами ЄС, $€$ більш розвиненими, а означає високий рівень розвитку всього Європейського регіону. Крім того, варто відмітити, що вищезазначені три країни-не члени $€ C, €$ важливими торгівельним партнерами та учасниками Єдиного ринку ЄС, тобто підвищують свій соціально-економічний рівень також споживаючи можливості ЄС.

Рівень нерівності доходів населення відображає наявність цієї нерівномірності. Результати за цим показником різняться доволі значимо між країнами, але зниження нерівності у 2018 р. в більшій частині країн, є позитивною характеристикою та формує тенденцію до зниження нерівномірності, що прямим чином впливає на зниження вірогідності зростання бідності населення.

Порівняння українських показників за двома аналізованими Індексами відображає, що Україна має найнижчий показник з тих країн, що аналізуються, хоча їі позиції в самому регіоні та у світі не $\epsilon$ останніми. Для нашої країни важливим $€$ вивчення досвіду $€ C$ для втілення в свої механізми управління державою та формування підґрунтя для вступу до ЄС.

Публікація підготовлена в рамках впровадження проєктів напряму Жана Монне: Проєкт «Європейські цінності різноманіття та інклюзії для сталого розвитку» Erasmust Jean Monnet Project "European Values of Diversity and Inclusion for Sustainable 
Development" (EVDISD) 620545-EPP-1-2020-1-UA-EPPJMO-PROJECT та Кафедра "Соціальні та культурні аспекти Європейських Студій» "Social and Cultural Aspects of European Studies" (SCAES) 620635-EPP-1-20201-UA-EPPJMO-CHAIR.

Зазначені проєкти фінансуються за підтримки Європейської Комісії. Публікація відображає точку зору лише автора і Комісія не може відповідати за будь-яке використання інформації, яка в ній міститься.

\section{Література:}

1. Вимірювання якості життя в Україні, Аналітична доповідь, Лібанова Е. М., Гладун О. М., Лісогор Л. С. та ін. К.: 2013, 48 с.

2. Дєліні М. М. Соціально-економічна відповідальність підприємництва: теорія, методологія, напрями розвитку: монографія. Краматорськ: ДДМА, 2017. 451 с.

3. Human Development Report (HDI) Ranking. United Nations Development Programme. URL: http://hdr.undp.org/en/content/latesthuman-development-index-ranking

4. Україна продовжує крокувати вперед до кращого розвитку людського потенціалу. URL: https://ukraine.un.org/uk/105324-ukrainaprodovzhue-krokuvati-vpered-do-kraschogo-rozvitku-lyudskogo-

potencialu

5. Quality life Index (2021). URL:https://www.numbeo.com/qual ity-of-life/rankings by country.jsp?title $=2021$-mid\&region $=150$

6. Eurostat. URL:https://ec.europa.eu/eurostat/statisticsexplained/index.php?title=Main Page

\section{References:}

1. Vymirjuvannja jakosti zhyttja v Ukraïni, Analitychna dopovidj, Libanova E. M., Ghladun O. M., Lisoghor L. S. ta in. K.: 2013, 48 s.

2. Djelini M. M. Socialjno-ekonomichna vidpovidaljnistj pidpryjemnyctva: teorija, metodologhija, naprjamy rozvytku: monoghrafija. Kramatorsjk: DDMA, 2017. $451 \mathrm{s.}$

3. Human Development Report (HDI) Ranking. United Nations Development Programme. URL: http://hdr.undp.org/en/content/latesthuman-development-index-ranking

4. Ukrajina prodovzhuje krokuvaty vpered do krashhogho rozvytku ljudsjkogho potencialu. URL: https://ukraine.un.org/uk/105324ukraina-prodovzhue-krokuvati-vpered-do-kraschogo-rozvitku-lyudskogopotencialuQuality life Index (2021). https://www.numbeo.com/qualityof-life/rankings by country.jsp?title=2021-mid\&region=150

5. Eurostat. URL:https://ec.europa.eu/eurostat/statisticsexplained/index.php?title=Main Page

The purpose of the article is to study the quality of life of the population of the EU and other European countries through various indicators and their comparison.

The term quality of life is inherently ambiguous, as it can refer to both the experience that a person has in their own life and the living conditions in which people live. Thus, the quality of life is also subjective due to the possibility of different interpretations by individuals. 
Quality of life is a qualitative characteristic in its essence, to which we refer those indicators that characterize the quality of life in the country, which cannot be expressed numerically. This is the satisfaction of the population with the level and quality of life in the country, the level and quality of life, which are measured by the Human Development Index, which consists of many components that take into account both the social and economic spheres. Analyzing its content, we can say that the Human Development Index (HDI) is one of the main indicators that reflects the quality of life of citizens. The Human Development Index is an integrated rating indicator that characterizes the degree of satisfaction of human needs and the level of ensuring their rights. HDI itself includes GDP per capita, which is calculated in dollars. US in terms of domestic prices, overall literacy rates and the number of years spent on education, life expectancy.

The provided analysis of statistics allows us to conclude that the EU and other European countries can be described as countries with one of the highest quality of life, as European countries are leaders in the Human Development Index, as well as among the Quality of Life Index. It should be noted that among the leaders are both EU member states (Denmark, Germany, Finland) and non-EU countries - Norway, Switzerland, Iceland. This result does not mean that those who are not members of the EU are more developed, but means a high level of development of the whole European region. In addition, it should be noted that the above three non-EU countries are important trading partners and participants in the EU Single Market, i.e. increase their socio-economic level also depends on consuming EU opportunities.

The level of income inequality reflects the existence of this inequality. The results of this indicator vary considerably between countries, but the reduction of inequality in 2018 in most countries is a positive characteristic and forms a tendency to reduce inequality, which directly affects the likelihood of increasing poverty.

The comparison of Ukrainian indicators according to the two analyzed Indices shows that Ukraine has the lowest indicator of the countries analyzed, although its positions in the region and in the world are not the last. It is important for our country to study the experience of the EU in order to implement it in its mechanisms of governing the state and to form the basis for for accession to the EU. 